\title{
STUDI LITERATUR PENGARUH PEMBERIAN EKSTRAK KEMANGI (Ocimum basilicum L.) TERHADAP KADAR KOLESTEROL TOTAL PADA TIKUS PUTIH (Rattus norvegicus) JANTAN GALUR WISTAR YANG DIBERI DIET TINGGI LEMAK
}

\author{
Dita Fitriani ${ }^{1}$, Neno Fitriyani Hasbie ${ }^{2}$, Zahrotul Fuadiyah ${ }^{3}$
}

\author{
${ }^{1}$ Departemen Fisiologi Fakultas Kedokteran Universitas Malahayati \\ ${ }^{2}$ Departemen Kesehatan Masyarakat Fakultas Kedokteran Universitas Malahayati \\ ${ }^{3}$ Program Studi Kedokteran Fakultas Kedokteran Universitas Malahayati
}

\begin{abstract}
Study of Literature Effect of Extracts Of Basil (Ocimum basilicum L.) on Total Cholesterol Levels of White Rat (Rattus norvegicus) Strain Male Wistar in High Fat Fed. Obesity is the accumulation of fat that is excessive due to no imbalance between the intake of energy with the energy that is used (energy expenditure) in a long time. Obesity has a close relationship with the incidence of hypercholesterolemia. Hypercholesterolemia is a condition when cholesterol concentrations in deep blood exceed normal limits. Hypercholesterolemia occurs due to the accumulation of cholesterol and lipids on the walls of blood vessels. Sweet basil is a known chemical compound such as compounds of phenolic and flavonoid acts as an antioxidant that can counteract the radical free. Animals try to use the mouse because having resemblance physiologically to humans and mice, including the animals, are easily maintained. This study aims to determine the effect of basil extract (Ocimum basilicum L.) on total cholesterol levels, to determine the dosage and duration of research that is effective in reducing total cholesterol levels. The method used for analysis is systematic literature review using database scholar.google.co.id and ncbi.mlm.nih.gov by using said key that is used to search the data to discover journals are associated with extracts of basil, cholesterol total, mice, and a diet high fat. The results of the study of the first three journals that have examined found that the levels of cholesterol in total experienced a decline that significant. Extract of basil (Ocimum basilicum L.) proved to be pr e clinical and clinical, able to lower the levels of cholesterol and as an attempt prevention of hyperlipidemia. The conclusion that can be drawn is that the extract of basil (Ocimum basilicum L.) can reduce total cholesterol levels, a dose of 350 and $700 \mathrm{mg} / \mathrm{kgBW}$ and the duration of administration of 30 days reduce total cholesterol levels by $>50 \%$.
\end{abstract}

Keywords : Obesity , Cholesterol Total, Extract basil , Rat White, High Fat Diet

\begin{abstract}
Abstrak: Studi Literatur Pengaruh Pemberian Ekstrak Kemangi (Ocimum basilicum L.) Terhadap Kadar Kolesterol Total pada Tikus Putih (Rattus norvegicus) Jantan Galur Wistar yang Diberi Diet Tinggi Lemak. Obesitas merupakan penumpukan lemak yang berlebihan akibat tidak seimbangnya asupan energi (energy intake) dengan energi yang digunakan (energy expenditure) dalam waktu lama. Obesitas memiliki hubungan erat dengan kejadian hiperkolesterolemia. Hiperkolesterolemia merupakan kondisi saat konsentrasi kolesterol dalam darah melebihi batas normal. Hiperkolesterolemia terjadi akibat akumulasi kolesterol dan lipid pada dinding pembuluh darah. Kemangi diketahui memiliki kandungan senyawa kimia seperti senyawa fenolik dan flavonoid berperan sebagai antioksidan yang dapat menangkal radikal bebas. Hewan coba menggunakan tikus dikarenakan mempunyai kemiripan fisiologis dengan manusia dan tikus termasuk hewan coba yang mudah dipelihara. Penelitian ini bertujuan untuk mengetahui pengaruh pemberian ekstrak kemangi (Ocimum basilicum L.) terhadap kadar Kolesterol total, mengetahui dosis dan lama penelitian yang efektif dalam menurunkan kadar
\end{abstract}


kolesterol total. Desain penelitian yang digunakan pada penelitian ini adalah desain penelitian deskriptif. Studi literatur (literature review) menggunakan database scholar.google.co.id dan ncbi.mlm.nih.gov dengan menggunakan kata kunci yang digunakan dalam pencarian data untuk menelusuri jurnal yang terkait dengan ekstrak kemangi, kolesterol total, tikus, dan diet tinggi lemak. Hasil penelitian dari 13 jurnal yang telah ditelaah didapatkan bahwa kadar kolesterol total mengalami penurunan yang signifikan. Ekstrak kemangi (Ocimum basilicum L.) terbukti secara preklinis dan klinis mampu menurunkan kadar Kolesterol dan sebagai upaya pencegahan hiperlipidemia. Kesimpulan yang dapat diambil bahwasannya ekstrak kemangi (Ocimum basilicum L.) dapat menurunkan kadar kolesterol total, dosis 350 dan $700 \mathrm{mg} / \mathrm{kgBB}$ dan lama pemberian 30 hari menurunkan kadar kolesterol total sebanyak $>50 \%$.

Kata Kunci : Obesitas, Kolesterol Total, Ekstrak Kemangi, Tikus Putih, Diet Tinggi Lemak

\section{PENDAHULUAN}

Obesitas

penumpukan lemak yang berlebihan akibat tidak seimbangnya asupan energi (energy intake) dengan energi yang digunakan (energy expenditure) dalam waktu lama. Obesitas memiliki hubungan erat dengan kejadian hiperkolesterolemia.

Hiperkolesterolemia merupakan kondisi saat konsentrasi kolesterol dalam darah melebihi batas normal. Hiperkolesterolemia terjadi akibat akumulasi kolesterol dan lipid pada dinding pembuluh darah (Listiyana et al., 2013). Kemangi diketahui memiliki kandungan senyawa kimia seperti senyawa fenolik dan flavonoid berperan sebagai antioksidan yang dapat menangkal radikal bebas (Erviana et al., 2016). Hewan coba menggunakan tikus dikarenakan mempunyai kemiripan fisiologis dengan manusia dan tikus termasuk hewan coba yang mudah dipelihara (Sella, 2019).

\section{METODE}

Penelitian ini menggunakan jenis penelitian kualitatif dengan desain penelitian deskriptif, dan menggunakan metode penelitian studi literatur dimana metode penelitian ini digunakan dengan tujuan utama yaitu untuk mengetahui pengaruh pemberian ekstrak kemangi terhadap kadar kolesterol total yang diberikan pada tikus putih.

Penelitian ini dilaksanakan pada bulan Januari tahun 2021. Penelitian dilakukan secara tidak langsung dengan mencari literatur-literatur ilmiah pada penelitian yang sudah ada sebelumnya dan akan dijadikan landasan pelaksanaan penelitian ini.

Data penelitian yang digunakan adalah jurnal publikasi di database scholar.google.co.id dan ncbi.mlm.nih.gov. yang dipilih dengan memperhatikan kriteria inklusi dan kriteria eksklusi, didapatkan jumlah sampel sebanyak 13 sampel. Hasil penelitian dapat dilihat pada tabel dibawah ini.

\section{HASIL}

Tabel 1. Persentase Penurunan Kadar Kolesterol Total

\begin{tabular}{ccccc}
\hline No & $\begin{array}{c}\text { Lama } \\
\text { pemberian }\end{array}$ & Penulis & Dosis $(\mathrm{mg} / \mathrm{kgBB} /$ hari) & $\%$ Penurunan \\
\hline 1 & 1 hari & Touiss et al. & 200 & $80 \%$ \\
& & $(2017)$ & 100 & $25 \%$ \\
2 & 2 Minggu & Ali et al. (2017) & 200 & $32.7 \%$ \\
3 & & Saha et al. (2012) & 50 & $-0.8 \%$ \\
4 & & 1500 & $-1 \%$ \\
& & Lodhi et al. (2019) & 50 & $-12 \%$
\end{tabular}




\begin{tabular}{|c|c|c|c|c|}
\hline & & & $\begin{array}{c}300 \\
2000\end{array}$ & $\begin{array}{l}-13 \% \\
-9 \%\end{array}$ \\
\hline 5 & 3 Minggu & Umar et al. (2012) & 800 & $20 \%$ \\
\hline \multirow[t]{6}{*}{6} & 4 Minggu & Nahal et al. (2012) & 350 & $51 \%$ \\
\hline & & (Aqueous) & 700 & $58 \%$ \\
\hline & & (Ethanol) & 350 & $54 \%$ \\
\hline & & & 700 & $62 \%$ \\
\hline & & Aqueous + ethanol & 350 & $53 \%$ \\
\hline & & & 700 & $62 \%$ \\
\hline \multirow[t]{2}{*}{7} & & $\begin{array}{l}\text { Soliman et al. } \\
\qquad(2020)\end{array}$ & 200 & $12.4 \%$ \\
\hline & & & 400 & $25 \%$ \\
\hline 8 & & $\begin{array}{l}\text { Touiss et al. } \\
\quad(2021)\end{array}$ & 200 & $15 \%$ \\
\hline 9 & 5 Minggu & $\begin{array}{c}\text { Harnafi et al. } \\
(2013)\end{array}$ & 200 & $47 \%$ \\
\hline \multirow[t]{2}{*}{10} & & $\begin{array}{c}\text { Ghazwani et al. } \\
\text { (2020) } \\
\text { (Unirradiated) }\end{array}$ & 400 & $24 \%$ \\
\hline & & (Irradiated) & 400 & $21 \%$ \\
\hline 11 & 6 Minggu & Sakr et al. (2011) & $\begin{array}{c}20 \mathrm{ml} / \mathrm{kgBB} 2 \\
\mathrm{kali} / \mathrm{minggu}\end{array}$ & $44 \%$ \\
\hline 12 & 9 Minggu & $\begin{array}{l}\text { Touiss et al. } \\
\text { (2019) }\end{array}$ & 200 & $47 \%$ \\
\hline 13 & 10 Minggu & $\begin{array}{c}\text { Harnafi et al. } \\
\text { (2009) }\end{array}$ & 500 & $43 \%$ \\
\hline
\end{tabular}

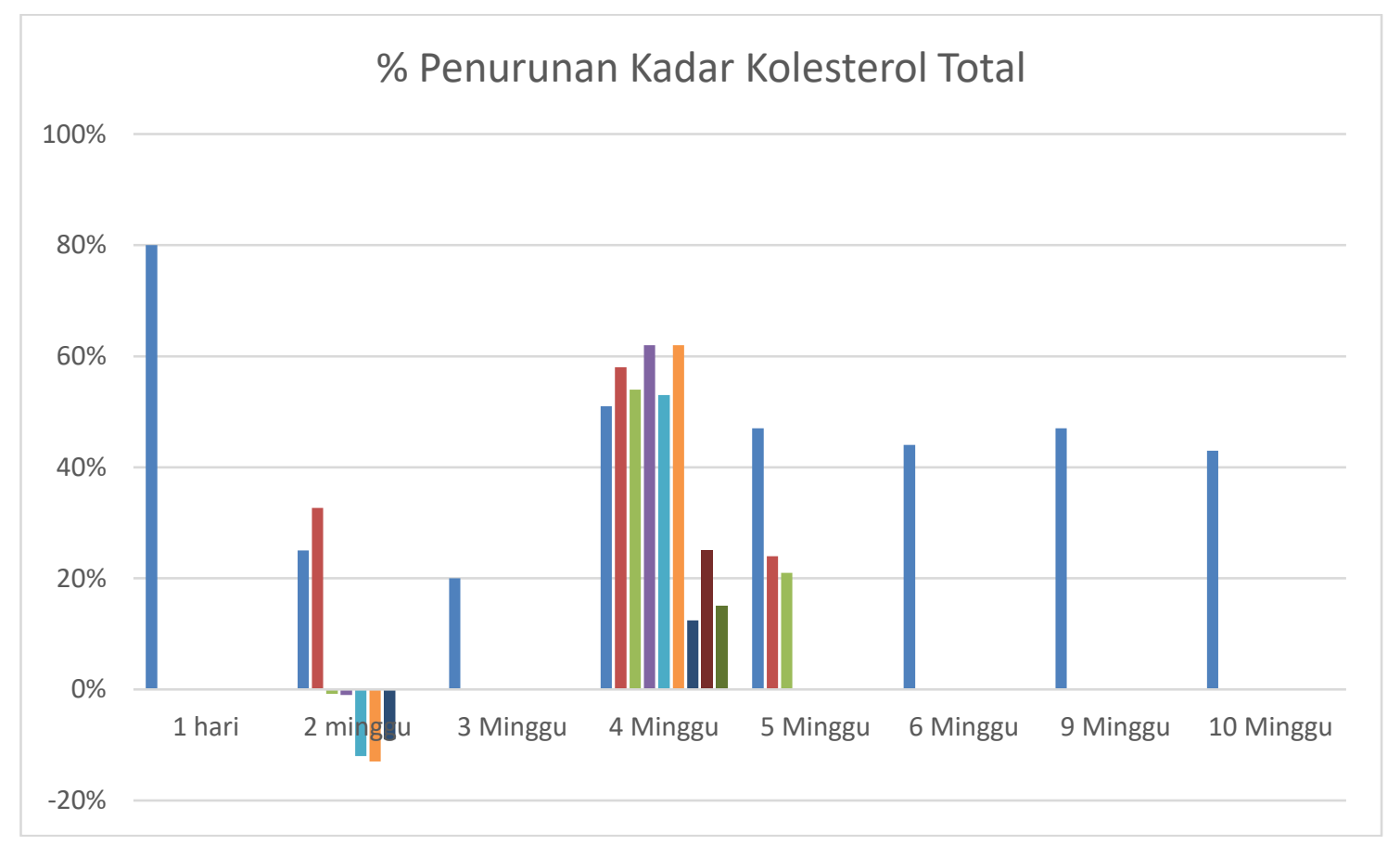

Gambar 1. Grafik Penurunan Kadar Kolesterol Total 
Tabel 2. Senyawa Pada Ekstrak Kemangi

\begin{tabular}{|c|c|c|}
\hline $\begin{array}{l}\text { GOLONGAN } \\
\text { SENYAWA }\end{array}$ & SENYAWA & PUSTAKA \\
\hline \multirow[t]{7}{*}{ polyphenol } & flavonoid & $\begin{array}{l}\text { Nahal et al.,2012; Ghazwani et al., 2020; Harnaf } \\
\text { et al., } 2009\end{array}$ \\
\hline & phenolic acid & Nahal et al.,2012; Ghazwani et al .,2020 \\
\hline & eugenol & Ghazwani et al., 2020; Saha et al., 2012 \\
\hline & estragole & Ghazwani et al., 2020 \\
\hline & methyl eugenol & \\
\hline & tanin & Ghazwani et al.,2020; Harnafi et al., 2009 \\
\hline & beta karoten & Ghazwani et al.,2020 \\
\hline \multirow[t]{22}{*}{$\begin{array}{l}\text { phenolic } \\
\text { acid }\end{array}$} & caftaric acid & $\begin{array}{l}\text { Touiss et al., 2019; Touiss et al., 2017; Harnafi } \\
\text { et al., } 2013\end{array}$ \\
\hline & caffeic acid & $\begin{array}{l}\text { Nahal et al., 2012; Touiss et al., 2019; Touiss et } \\
\text { al., 2017; Harnafi et al., } 2013\end{array}$ \\
\hline & chicoric acid & $\begin{array}{l}\text { Touiss et al., 2019; Touiss et al., 2017; Harnafi } \\
\text { et al., } 2013\end{array}$ \\
\hline & rosmarinic acid & $\begin{array}{l}\text { Nahal et al., 2012; Touiss et al., 2019; Touiss et } \\
\text { al., 2017; Harnafi et al., } 2013\end{array}$ \\
\hline & geraniol & Saha et al., 2012 \\
\hline & Citral & \\
\hline & a- Pinene & \\
\hline & Camphor & \\
\hline & geraniol & \\
\hline & Cineole & \\
\hline & $\beta$-Pinene & \\
\hline & Citronellal & \\
\hline & Vanillin & \\
\hline & Linalool & \\
\hline & Pyrogallol & Nahal et al., 2012 \\
\hline & Protocatchuic & \\
\hline & catechein & \\
\hline & catechol & \\
\hline & Vanillic acid & \\
\hline & Ferulic acid & \\
\hline & $\begin{array}{c}p- \\
\text { Hydroxybenzoid } \\
\text { acid }\end{array}$ & \\
\hline & caffeine & \\
\hline \multirow[t]{7}{*}{ Flavonoid } & Rutin & Nahal et al., 2012 \\
\hline & Quercitrin & \\
\hline & Kampferol & \\
\hline & Apigenin & \\
\hline & Naringenin & \\
\hline & Quercetin & \\
\hline & glutamic acid & Ghazwani et al.,2020 \\
\hline
\end{tabular}




\begin{tabular}{c}
\hline aspartic acid \\
1,2,4-Triazole \\
$4-[\mathrm{N}-(2-1$ \\
hydroxyethyl)-N- \\
nitro] amino \\
alanin \\
leucine \\
glycine \\
\hline
\end{tabular}

\section{PEMBAHASAN}

Berdasarkan dosis dan lama pemberian ekstrak kemangi, diketahui bahwa pada penelitian yang berlangsung 1 hari, Touiss et al. (2017) menunjukkan bahwa ekstrak kemangi dengan dosis $200 \mathrm{mg} / \mathrm{kgBB}$ menurunkan kadar kolesterol total hingga $80 \%$. Dan selama 2 minggu, penelitian Ali et al. (2017) pemberian dosis sebanyak $100 \mathrm{mg} / \mathrm{kgBB} /$ hari dapat menurunkan kadar kolesterol total sebanyak $25 \%$, dan dosis $200 \mathrm{mg} / \mathrm{kgBB}$ menurunkan sebanyak 32,7\%. Dengan waktu yang sama, Saha et al. (2012) menunjukan bahwa dosis $50 \mathrm{mg} / \mathrm{kgBB}$ dan $1500 \mathrm{mg} / \mathrm{kgBB}$ tidak menurunkan kadar kolesterol total. Dan pada penelitian Lodhi et al. (2020) menunjukkan bahwa pemberian dosis sebanyak $50 \mathrm{mg} / \mathrm{kgBB}, 300 \mathrm{mg} / \mathrm{kgBB}$, dan $2000 \mathrm{mg} / \mathrm{kgBB}$ tidak menurunkan kadar kolesterol total.

Pada pemberian selama 3 minggu, pada penelitian Umar et al. (2012) didapatkan bahwa dosis $800 \mathrm{mg} / \mathrm{kgBB}$ menurunkan kadar kolesterol total sebanyak $20 \%$, lebih sedikit dibandingkan Ocimum suave dengan dosis yang sama, menurunkan sebesar $52 \%$ dan Lipitor sebanyak $167 \mu \mathrm{g} / \mathrm{kgBB}$ yang menurunkan hingga $75 \%$.

Pada pemberian selama 4 minggu, penelitian Nahal et al. (2012) menunjukan bahwa pemberian ekstrak aqueous kemangi dengan dosis 350 $\mathrm{mg} / \mathrm{kgBB}$ dan $700 \mathrm{mg} \mathrm{mg} / \mathrm{kgBB}$ menurunkan kadar kolesterol total sebesar $51 \%$ dan $58 \%$. Ekstrak etanol kemangi dengan dosis yang sama menurunkan sebanyak 54\% dan $62 \%$. Ekstrak etanol dan aqueous dengan dosis yang sama menurunkan sebanyak $53 \%$ dan $62 \%$.
Dengan waktu yang sama, Soliman et al. (2020) menunjukkan bahwa dosis kemangi sebanyak 200 $\mathrm{mg} / \mathrm{kgBB}$ dan $400 \mathrm{mg} / \mathrm{kgBB}$ menurunkan kadar kolesterol total sebanyak $12,4 \%$ dan $25 \%$. Dan pada penelitian Touiss et al. (2021) menunjukkan bahwa dosis 200 $\mathrm{mg} / \mathrm{kgBB}$ dapat menurunkan kadar kolesterol total sebanyak $15 \%$.

Selama 5 minggu, penelitian Harnafi et al (2013) menunjukkan bahwa pemberian ekstrak kemangi dengan dosis $200 \mathrm{mg} / \mathrm{kgBB}$ menurunkan sebanyak $46 \%$, sedangkan pemberian fenofibrate dengan dosis yang sama hanya menurunkan sebesar $28 \%$. Dan pada penelitian Ghazwani et al. (2020) dengan lama yang sama dan dosis $400 \mathrm{mg} / \mathrm{kgBB}$, kemangi yang tidak diradiasi menurunkan sebanyak $24 \%$ dan kemangi yang sebelumnya diradiasi menurunkan sebesar $21 \%$.

Pada pemberian selama 6 minggu, penelitian Sakr et al. (2011) dengan dosis $20 \mathrm{ml} / \mathrm{kgBB}$ dua kali/minggu menurunkan $21 \%$ pada pemeriksaan di minggu ke-2, 25\% di minggu ke-4, dan menurunkan sebanyak $44 \%$ pada pemeriksaan di minggu ke 6.

Pada pemberian selama 9 minggu, penelitian Touiss et al. (2019) menunjukkan bahwa pemberian ekstrak asam rosmarinik dari ekstrak kemangi dengan dosis $200 \mathrm{mg} / \mathrm{kgBB}$ menurunkan kadar kolesterol total sebanyak $47 \%$, dan fenofibrat dengan dosis yang sama menurunkan lebih sedikit, yaitu hanya $43 \%$. Pada pemberian selama 10 minggu, Harnafi et al. (2009) menunjukkan bahwa dosis $500 \mathrm{mg} / \mathrm{kgBB}$ menurunkan kadar kolesterol total sebanyak $44 \%$ di minggu ke-2, $40 \%$ di minggu ke- $6,37 \%$ 
di minggu ke- 8 , dan $43 \%$ di minggu ke10.

Berdasarkan jenis ekstraksi nya, dari 13 jurnal penelitian yang ditelaah, kemangi diekstrak dengan jenis ektraksi yang berbeda. Didapatkan bahwa 8 penelitian melakukan ekstraksi dengan menggunakan air sulingan, sehingga menjadi aqueous ekstrak kemangi. 1 penelitian menggunakan etanol $70 \%$, pada penelitian, 1 penelitian menggunakan etanol 95\%, 2 penelitian menggunakan metanol, dan 1 penelitian melakukan perbandingan dengan menggunakan air sulingan dan etanol sebagai bahan ekstraksi pada pembuatan ekstrak kemangi. (Harnafi et al., 2013; Sakr et al., 2011; Ali et al., 2012; Nahal et al.,2012; Saha et al., 2012; Umar et al., 2012; Lodhi et al., 2019; Touiss et al.; 2019; Ghazwani et al.,2020; Soliman et al.; 2020; Touiss et al., 2021).

Pemberian ekstrak kemangi dengan dosis dan lama pemberian yang berbeda dapat memberikan efek yang sama yaitu terjadinya penurunan kadar kolesterol total. Hal ini dikarenakan terdapat kandungan antioksidan dan antihiperlipidemia seperti flavonoid, asam fenolik, dan asam rosmarinik yang terkandung dalam kemangi sehingga dapat menurunkan kadar kolesterol total dalam darah. Kandungan senyawa tersebut umumnya ditemukan di bagian daun kemangi, dan senyawa asam rosmarinik dapat ditemukan di seluruh bagian tanaman kemangi (Marwat et al., 2011).

Berdasarkan empat penelitian yang ditelaah, diidentifikasikan bahwa ekstrak kemangi mengandung flavonoid yang memiliki kinerja yang mirip dengan obat anti-hiperkolesterol golongan statin, yaitu dengan menghambat HMG-COA reductase. Dimana penghambatan HMG-CoA reduktase menyebabkan penurunan konsentrasi kolesterol dalam hepatosit. Dan mekanisme ini juga diperankan oleh Asam Fenolik dan beta karoten (Harnafi et al., 2013; Touiss et al., 2017). Selain itu, Flavonoid juga meningkatkan LCAT yang merupakan enzim yang mengubah kolesterol bebas menjadi kolesterol ester (bentuk kolesterol yang lebih hidrofobik), yang akan berikatan pada HDLs (a-LCAT) dan LDLs ( $\beta$ LCAT) dalam plasma darah sehingga meningkatkan kadar HDL dan menurunkan kadar LDL (Nahal et al., 2012; Ghazwani et al., 2019; Harnafi et al., 2009).

Pada Penelitian Ghazwani et al. (2012) didapatkan bahwa ekstrak kemangi mengandung Tanin dan Beta Karoten, dimana Beta Karoten memiliki kerja yang sama seperti Flavonoid dalam menurunkan kadar kolesterol total dan Tanin menurunkan kolesterol total dengan meningkatkan laju metabolisme kolesterol menjadi asam empedu dan meningkatkan ekskresi asam empedu melalui feses.

Sedangkan pada penelitian Touiss et al. (2017 dan 2019), didapatkan bahwa asam rosmarinik dari ekstrak kemangi dapat menurunkan kadar kolesterol total dengan mekanisme yang berbeda dari asam fenolik, yaitu dengan peningkatan aktivitas Lesitin-Kolesterol Asil-Transferase (LCAT). Selain itu, asam rosmarinik dari ekstrak tersebut dapat merangsang katabolisme cepat LDL-C melalui reseptor hati sebagai jalur utama untuk eliminasi akhir kolesterol dalam empedu sehingga menurunkan kadar kolesterol total.

Namun terdapat 2 penelitian yang berbanding terbalik dengan hasil penelitian lainnya. Yakni pada penelitian Saha et al. (2012) dan penelitian Lodhi et al. (2019). Hal ini dikarenakan pada penelitian Saha et al. (2012) dan Lodhi et al. (2019), menggunakan desain penelitian post test only with control group design sehingga kadar kolesterol total tidak dapat dibandingkan. Dan pada penelitian pada 2 penelitian tersebut tidak menggunakan kelompok kontrol negatif sebagai kelompok pembanding dengan kelompok uji.

\section{KESIMPULAN}

Berdasarkan hasil dari penelitian mengenai pengaruh pemberian ekstrak kemangi terhadap kadar kolesterol total, diperoleh beberapa kesimpulan Pemberian ekstrak kemangi (Ocimum basilicum L.) dapat menurunkan kadar 
kolesterol total. Pemberian ekstrak kemangi (Ocimum basilicum L.) dengan dosis $350 \mathrm{mg} / \mathrm{kgBB}$ dan $700 \mathrm{mg} / \mathrm{KgBB}$ per hari dapat menurunkan kadar kolesterol total hingga $>50 \%$. Pemberian ekstrak kemangi (Ocimum basilicum L.) dengan lama pemberian selama 30 hari dapat menurunkan kadar kolesterol total hingga $>50 \%$.

\section{DAFTAR PUSTAKA}

Ali, A., Qasim, M., Aftab, M.N., Azam, S.M., Iqbal, F., Akram, S., dan Hussain, M.Z. (2017). Effect of Ocimum basilicum Extract on Hematological and Serum Profile of Male Albino Mice After $\mathrm{AlCl} 3$ Induced Toxicity. Pure and Applied Biology 6(2): 505-510.

Erviana, L., Malik, A., \& Najib, A. (2016). Uji Aktivitas Antiradikal Bebas Ekstrak Etanol Daun Kemangi (Ocimum basilicum L.) Dengan Menggunakan Metode DPPH. Jurnal Fitofarmaka Indonesia 3(2).

Ghazwani, A.H., Osman, N.N., and Basalamah, K.S. (2020). Role of Gamma-irradiated Basil (Ocimum basilicum) in the Alleviation of Heart Toxicity Induced by Arsenic in Rats. International Journal of Pharmaceutical and Phytopharmacological Research (eIJPPR) 10(2): 101-109.

Harnafi, H., Aziz, M., \& Amrani, S. (2009). Sweet Basil (Ocimum basilicum) Improves Lipid Metabolism Hypercholesterolemic Rats. Clinical Nutrition ESPEN 4(4): 181-186.

Harnafi, H., Ramchoun, M., Tits, M., Wsuters, J-N., Frederich, M., Angenot, L., et al. (2013). Phenolic Acid-Rich Extract of Sweet Basil Restores Cholesterol and Tryglicerides Metabolism in High Fat Diet-Fed Mice: A Comparison With Fenofibrate. Biomedicine and Preventive Nutrition 3(4): 393-397.

Listiyana, A.D., Mardiana, Prameswari, G.N. (2013). Obesitas Sentral dan Kadar Kolesterol Total. Jurnal Kesehatan Masyarakat 9(1).
Lodhi, B.A., Hussain, M.A., Ashraf, M.U., Farid-ul-haq, M., Haseeb, M.T., and Tabassum, T. (2020). Acute Toxicity of A Polysaccharide-Based Hydrogel from Seeds of Ocimum basilicum. Cellulose Chemistry and Technology 54(3-4): 291-299.

Marwat, S.K., Fazal-Ur-Rehman., K., Muhammad, S.K, Said, G., Naveed, A., Ghulam, M., and Khalid, U. (2011). Phytochemical Constituents and Pharmacological Activities of Sweet Basil-Ocimum basilicum L. (Lamiaceae). Asian Journal of Chemistry 23(9): 37733782.

Nahal, D.E, Hala, T., and Sayed, F. (2012). Study The Impact of Sweet Basil Extracts (Ocimum basilicum) to Reduce Blood Cholesterol. Egyptian Journal of Nutrition and Health 7(1): 51-68.

Saha, S., Mukhooadhyay, M.K., Ghosh, P.D., and Nath, D. (2012). Effect of Methanolic Leaf Extract of Ocimum basilicum L. on BenzeneInduced Hematotoxicity in Mice. Hindawi Evidence-Based Complementary and Alternative Medicine.

Sakr, S.A., El-Abd, S.F., Osman, M., Kandil, A.M., and Helmy, M.S. (2011). Amerolative Effect of Aqueous Leaf Extract of Ocimum basilicum on Ccl4-Induced Hepatotoxicity and Apoptosis in Albino Rats. Journal of American Science 7(8): 116-127.

Sella, A. P. (2019). Efek Ekstrak Etanol Daun Cocor Bebek (Kalanchoe Pinnata [Lam] Pers.) Terhadap Waktu Penyembuhan Luka Sayat Pada Tikus Putih Jantan Galur Wistar. Journal of Chemical Information and Modeling 53(9): 1689-1699.

Soliman, A.M., Rizk, M.A., Shalaby, M.A., Elkomy, A.A. (2020). Mechanisms of Hepato-Renal Protective Activity of Ocimum basilicum Leaf Extract against Paracetamol Toxicity in Rat Model. Advance In Animal and Veterinary Science 8(4): 385-391. 
Touiss, I., Khatib, S., Bekkouch, O., Amrani, S., Harnafi, H. (2017). Phenolic Extract from Ocimum basilicum Restores Lipid Metabolism in Triton WR-1339Induced Hyperlipidemic Mice and Prevents Lipoprotein-Rich Plasma Oxidation. Biomedicine and Preventive Nutrition 25(3): 254262.

Touiss, I., Harnafi, M., Khatib, S., Bekkouch, O., Amrani, S., \& Harnafi, H. 2019. Rosmarinic AcidRich Extract From Ocimum basilicum L. Decreases Hyperlipidemia In High Fat DietInduced Hyperlipidemic Mice And Prevents Plasma Lipid Oxidation. Physiology and Pharmacology 23: 197-207.

Touiss, I., Ouahhoud, S., Harnafi, M., Khatib, S., Bekkouch, O., Amrani, S., and Harnafi, H. (2021). Toxicological Evaluation and Hepatoprotective Effect of Rosmarinic Acid-Rich Extract from Ocimum basilicum L. Hindawi Evidence-Based Complementary and alternative Medicine.

Umar, I. A., Mohammed, A., Dawud, F. A., Kabir, A. M., Sai, J. V., Muhammad, F. S. and Okalor, M. E. (2012). The Hypolipidepemic and Antioxidant Action of Ocimum basilicum and Ocimum suave in High Fat Fed Rats. Journal of Medical Plants Research 6(18): 3501-3505. 